Marquette University

e-Publications@Marquette

College of Communication Faculty Research and

Publications

Communication, College of

8-1-2011

\title{
Adopting an Attitude of Wisdom in Organizational Rhetorical Theory and Practice: Contemplating the Ideal and the Real
}

Rebecca J. Meisenbach

University of Missouri - Columbia

Sarah Bonewits Feldner

Marquette University, sarah.feldner@marquette.edu

Published version. Management Communication Quarterly, Vol. 25, No. 3 (August 2011): 560-568.

DOI. (C) 2011 The Authors. Used with permission. 


\section{Management Communication Quarterly \\ http://mcq.sagepub.com/}

\section{Adopting an Attitude of Wisdom in Organizational Rhetorical Theory}

and Practice: Contemplating the Ideal and the Real

Rebecca J. Meisenbach and Sarah Bonewits Feldner Management Communication Quarterly 2011 25: 560 originally published online 28 June 2011

DOI: $10.1177 / 0893318911409548$

The online version of this article can be found at:

http://mcq.sagepub.com/content/25/3/560

\section{Published by:}

(S) SAGE

http://www.sagepublications.com

Additional services and information for Management Communication Quarterly can be found at:

Email Alerts: http://mcq.sagepub.com/cgi/alerts

Subscriptions: http://mcq.sagepub.com/subscriptions

Reprints: http://www.sagepub.com/journalsReprints.nav

Permissions: http://www.sagepub.com/journalsPermissions.nav

Citations: http://mcq.sagepub.com/content/25/3/560.refs.html

>> Version of Record - Aug 10, 2011

OnlineFirst Version of Record - Jun 28, 2011

What is This? 


\title{
Adopting an Attitude of Wisdom in \\ Organizational \\ Rhetorical Theory \\ and Practice: \\ Contemplating the \\ Ideal and the Real
}

Management Communication Quarterly

25(3) 560-568

(C) The Author(s) 2011

Reprints and permission: http://www. sagepub.com/journalsPermissions.nav

DOI: | 0.1 | $77 / 08933$ |89| |409548 http://mcq.sagepub.com

๑SAGE

\author{
Rebecca J. Meisenbach' \\ and Sarah Bonewits Feldner ${ }^{2}$
}

\begin{abstract}
Research and practice in external rhetoric often fall short of ideals both in terms of widespread use of a rhetorical perspective and in achieving dialogic conditions in the public sphere. In this response, the authors consider potential explanations for this shortfall, focusing on challenges that exist on a theoretical level within organizational rhetoric scholarship and on a practical level as individuals and organizations interact.
\end{abstract}

\section{Keywords}

organizational rhetoric, dialogue, ethics, materiality

The more we learn about a particular domain, the greater the number of uncertainties, doubts, questions and complexities. Each bit of knowledge serves as

\footnotetext{
'University of Missouri, Columbia, MO, USA

${ }^{2}$ Marquette University, Milwaukee, WI, USA

\section{Corresponding Author:}

Rebecca J. Meisenbach, Department of Communication, University of Missouri,

II 5 Switzler Hall, Columbia, MO 652I I

Email: meisenbachr@missouri.edu
} 
the thesis from which additional questions or antithesis arise. (Meacham, as cited in Weick, 1993, p. 641)

The year 2010 will undoubtedly be remembered for many events; yet, as scholars of organizational rhetoric, we imagine that 2010 will be remembered in part for the rhetorical successes and failures of the Toyota Corporation and British Petroleum (BP) as both sought to manage their identities and rebuild their legitimacy in the wake of their current crises. We are struck by how each case reflects not how far public relations has come since the 1980s when Exxon Mobil and Johnson \& Johnson's Tylenol brand faced crises of a similar scale, but rather how little seems to have been learned. In various ways, each company's responses violated expectations for an "ideal" rhetorical response, and yet, in the "real" of company life, Toyota seems to be on the mend, and we anticipate that BP will recover as well. Many scholars and practitioners may ponder why that is. Such musings remind us of a notion of wisdom present in Karl Weick's groundbreaking work on sensemaking (1993, 1995); the more that scholars uncover and learn about something (such as the contributions of organizational rhetoric to society) the more questions and challenges that emerge.

In responding to this special issue, we argue that such wisdom might help us attend to the many questions that remain about the status of external organizational rhetoric scholarship and practice. One thing that is clear in reading the articles in this issue - the body of research in organizational rhetoric is deep and rich, and the potential for its further contribution to management and organizational communication is great. These articles left us considering and debating the boundaries and relationships among the ideal (that which people hope for organizational rhetoric) and the real (the material conditions that impact the role of rhetoric in organizational life). Our goal here is not to eliminate gaps between the ideal and the real, but rather to discuss some of the questions and opportunities that emerge as we consider the juxtaposition. In particular, we use the contrast between the ideal and the real to discuss the answers offered in this special issue to Heath's main question about whether and how organizational rhetoric makes and can make society a better place. At the same time, we ask why organizational rhetoric scholarship over the past 20 years has not yet seemed to foster the positive contributions to society that scholars might hope.

\section{Sketching Out Ideal(s)}

This issue's contributing authors share an interest in bettering society, and many of them turn to dialogue as a standard for organizational rhetoric. 
These contributions offer a blend of theoretical perspectives, applied approaches, and critique of current scholarship. The common thread that holds them together is a vision for what organizational rhetoric can be in its best or ideal form. This is a vision of organization-public communication that is rooted in dialogue and constitutive of community. On another level, these articles reveal an ideal of organizational rhetoric scholarship, scholarship that takes rhetorical theory seriously to understand better how organization/society relationships are created, managed, and sometimes destroyed.

First, in terms of dialogic ideals, both Heath and Taylor's articles remind readers of how public relations scholarship has focused on dialogue as its ethical ideal because it allows organizations and publics to make enlightened choices and build social capital, which in turn make society better. Although not explicitly invoking dialogue as a standard, Coombs and Holladay invite its consideration as they argue that ideal self-regulatory discourse should empower constituents with the tools to protect themselves; thus, a standard of engagement with external stakeholders is created. Even in suggesting that dialogue might be unattainable, Boyd and Waymer's case for transparency surrounding corporate self-interest clears space for dialogue in one sense. Transparency of communication theoretically allows publics to consider organizational arguments in an unfettered way; that is, transparency would be seen as necessary for dialogue.

On a second level, this special issue calls attention to the notion that serious contemplation and integration of classical and new rhetorical theory allows scholars to better achieve the ideal of dialogue that betters society. All of the authors note the degree to which rhetorical theories/concepts enhance understanding of organization/society interaction. Ihlen explicitly argues for focusing on classical rhetorical theory in a public relations context. He joins other scholars (e.g., Hoffman \& Ford, 2010) in suggesting that organizational messages must be understood and critically questioned within the context of the rhetorical situation. Boyd and Waymer invoke the rhetorical construct of the public sphere to show how organizations might argue for the ethicality of their practices. Frandsen and Johansen connect institutional theory, and Taylor connects social capital research to the study of organizational rhetoric. Noting the rhetorical theories and concepts that these contributions invoke may seem at first glance self-evident; however, we believe that this contribution should not be overlooked because the richness and range of theory used in these pieces point toward an ideal of organizational rhetoric scholarship grounded in theory. These essays suggest that scholars and practitioners within organizational communication, corporate communication, and public relations have learned a great deal about how we all might enact dialogue; 
yet, theories and practice seem to fall short of reaching this ideal. The question remains as to why.

\section{Addressing the "Real": Challenges in Theory and in Practice}

Today's reality is one in which research and practice in external rhetoric often fall short of ideals both in terms of widespread use of a rhetorical perspective and in achieving dialogic conditions in the public sphere. The authors in this issue have offered some potential explanations. In what follows, we consider these suggestions and offer some thoughts about other obstacles to achieving ideals. In particular, we address the challenges faced on a theoretical level in organizational rhetoric scholarship and those challenges that exist on a practical level as individuals and organizations encounter the reality of their situatedness.

First, we are reminded of definitional issues that limit broad understanding and use of a rhetorical perspective in communication and management research. The articles in this issue carefully introduce and define concepts such as civil society, issues management, and institutions. Yet, the articles also draw attention to one challenging definitional issue - discourse as it relates to rhetoric. Some contributors use these concepts in a way that suggests that the two are interchangeable (e.g., Taylor's articulation of rhetoric "as the discourse") whereas others seem to suggest that they are distinct concepts. For example, Frandsen and Johansen treat discourse and rhetoric as discrete concepts, with rhetoric described as a product of various discourses (e.g., a political green discourse). Ihlen and Heath seem to share Putnam and Fairhurst's (2001) and Bitzer's (1968) articulation of rhetoric as a specific form of discourse. Finally, Boyd and Waymer at times use discourse to indicate talk, yet their discussion of outlaw discourse seems to equate discourse with persuasion, which others define as rhetoric.

Although we believe that there can be multiple useful definitions and relations among these terms and that rhetoric can be usefully viewed as both a process and a product, our point here is that scholars of organizational rhetoric should consider the potential for slippage and confusion among some of the area's most basic terms. Those who peer in from the outside at an organizational rhetoric perspective may understandably be unclear about the relation among these terms and consequently hesitate to dive in. Thus, we encourage organizational rhetoric scholars to work to make those definitions clear in each presentation of their research. 
A second challenge rooted in organizational rhetoric scholarship is adherence to the rhetorical ideal of grounding analysis in the text. We argue that this grounding in the text is a strength of a rhetorical approach. Yet a survey of the scholarship in this area suggests that often the focus on text is diluted as scholars seek to address theoretical frameworks and broader contextual issues. In the end, analyses can lack focus on the actual arguments offered by organizations - with discussions focusing on the fact that organizations spoke without offering a close description of how they spoke. In this special issue, the primary focus of these authors was in developing theoretical frameworks for external rhetoric. However, in considering examples for others of this kind of analysis, we found ourselves yearning for more from the texts in the case studies used to advance theoretical claims. For example, we are engaged by the notion that NGOs sought out participation from community members, but also wonder about the language used to request that participation. We agree that self-regulatory discourse can do a better or worse job at empowering stakeholders but wonder what does that empowering discourse (such as PhRMA's "Guiding Principles" document) actually say. The challenge is one of balancing text and context as well as theory and practice.

Although we have just noted that a strength of a rhetorical approach is its focus on the text, rhetorical scholars also must grapple with the power of the material. The strong focus on context in the contributions in this issue, such as Ihlen's focus on in-depth consideration of the rhetorical situation, pushes our scholarship in that direction. Cloud (1994) has warned critical rhetoricians about the danger of assuming that discourse not only influences reality, but also is reality; that is, she cautions against believing that there is nothing outside of the text. We particularly want to call attention to how material changes in our global society impact rhetorical efforts.

First, as society becomes more global and networked, organizations face increasingly complex conditions in seeking to engage constituents. The authors in this issue highlight some of these challenges. For example, in Taylor's compelling example of an attempt at two-way communication between Jordanian government and neighborhood coalitions, she notes how the material resources and power of government donors, along with the urgent need for workers and a lack of media outlets in Aqaba, all contribute to the development of the neighborhood groups (NETs) and the communication between the NETs and governing body ASEZA. Although this case highlights organizations that at one level are successfully navigating the complexity of today's global society, we also note the material limit on the dialogue in this case. Although participation is allowed, the streamlined process is one in which community members appear to be allowed to participate in limited ways - that is, they discuss issues from a 
preselected list of options. Community members' "enlightened choices" seem to be limited to predetermined problems that someone else has decided are present.

Thus, materiality affects dialogic ideals that all voices and interests can participate in the public sphere on relatively equal terms such that the best idea wins out in the "wrangle of the marketplace" (Burke, 1969, p. 23). In this context, Boyd and Waymer (2011) argue that organizational material resources mean that organizational self-interest is more influential than individual self-interest and that, therefore, hopeful dialogic rhetors have only an "illusion of equal access to whatever counts as a "public sphere" (p. 479). We extend their argument to note also that certain types of organizations have more resources than other organizations. For example, consider the large disparity in the United States between possible and legal political campaign contributions from for-profit corporations in comparison to those possible from nonprofit organizations. Corporations often have more material resources supporting them and fewer regulations constraining them than do NGOs that seek to represent groups of individual interests. These resource imbalances create challenges for scholars and practitioners who pursue dialogue as their ideal for public relations.

Technology is another material condition that these articles suggest impacts organizational rhetoric. Coombs and Holladay discuss how online media is impacting and accelerating the rhetorical management of issues through their life cycles. Much of the global influence on Jordanian communication processes that Taylor discusses is achieved through enhanced technologies such as email communication. Similarly, Boyd and Waymer note that social media may actually persuade (or force) corporations to increase their responsiveness to public interests. For example, recently Disney dissidents were able to use a website to voice their dissatisfaction with Disney executives in a way that resulted in changes in the membership and leadership of the board; the Internet gave voice to a previously silenced position (Feldner \& Meisenbach, 2007). Thus, we think that technology plays a very real role in the future of organizational rhetoric by challenging organizations to manage all the stakeholders that now have access to public voice. Although more voices are present in interaction via technology, these voices are largely unrestrained and uncoordinated - potentially creating noise or an illusion of dialogue without meaningful engagement among voices. Technology allows for access but does not necessarily contribute to the quality of arguments. Thus, technology is one of many aspects of material reality that is simultaneously an opportunity and challenge for dialogue. 


\section{Proceeding With Wisdom}

This special issue raises hopes in setting out ideal contributions for organizational rhetoric; yet the issue simultaneously calls attention to ways in which the real (i.e., material conditions) generates daunting obstacles. In facing what seems to be an impasse, we return to Weick's notion of wisdom - calling for wisdom that leads scholars and practitioners to be mindful of the dichotomies that they themselves create (e.g., rhetorical solutions as either wholly dialogic or not dialogic, theoretical frameworks as feasible or simply not attainable). As scholars and practitioners, we can adopt a stance that recognizes that we know enough about organizational existence in the context of a complex world to know that we do not know exactly how to enact these dialogic ideals in that world. And yet, organizational rhetoric does offer theories, perspectives, and insights that can help manage this tension.

Although there are numerous dichotomies to consider, one stands out as an exemplar that embodies the ideal/real tension. We are cognizant of criticism that dialogic frameworks, while admirable, are hyperbolic at best (Boyd \& Waymer, 2011), and yet, we think there is a certain wisdom in retaining dialogue's idealism alongside this reality. A dichotomy of hyperbolic idealism versus pragmatic realism limits our ability to work toward theory and practice that frames external rhetoric as a vehicle for creating a more engaged society.

Boyd and Waymer offer a resolution to the conundrum of ethical organizational rhetoric by suggesting an acceptance of the idea that the very nature of the corporation is to be self-interested. In response, publics should ask corporations to be transparent about their self-interested motives. This proposition embodies the "real" in that it faces the challenges of a society in which corporate logic prevails and "corporatism" has become a primary decisionmaking premise (see Deetz, 1992). Although this shift might offer a new ideal of honest communication practices through transparent disclosure of self-interest, we question the lowered expectations that this move creates. Deetz (2008) argues that as scholars seeking engaged scholarship, we need to be mindful not only of what our audiences do with the knowledge that we produce, but also "what we and they become in producing this rather than that knowledge" (p. 291). Fully accepting a corporate ethic of self-interest seems to abandon the belief that corporations can and should serve more than the interests of the capitalist at the top of the organization. How many individuals live only for their own interests, and how accepting is society of those who do? We posit (and yes, idealistically hope) that society is not so accepting of such a stance. If organizations are made up of relations among people, 
then when a group of individuals organizes into a formal collective, why would it become acceptable for it to only serve the collective's interests? Furthermore, self interest as an ethical standard appears to be incompatible with many of the tenets of dialogue identified by Kent and Taylor (2002, see also Taylor, 2011), including empathy, risk, and commitment. Thus, on one hand, for those who wish to balance the ideal and the real in pursuit of dialogic organizational rhetoric, Boyd and Waymer clarify that self-interest is an obstacle in itself that must be addressed to achieve balance. They advocate managing it by embracing it. However, we urge consideration of whether accepting the primacy of organizational self-interest leans so far from ideals that it cuts off opportunities to pursue better rhetoric by maintaining a productive and change-oriented tension between the ideal and the real.

In conclusion, the authors in this special issue affirm a practical hopefulness as they tackle the realities of a changing society, examining questions ranging from self-regulatory discourse to environmental legitimacy to corporate self-interest. In taking on these complex issues, there remains optimism that, at its best, external rhetoric can be more dialogic as Taylor demonstrates, and organizational arguments can create conditions that invite stakeholder response and participation as Coombs and Holladay and Frandsen and Johansen suggest. However, as Boyd and Waymer rightfully note, scholars cannot lose sight of the real as they promote these ideals. As the Toyota and BP cases illustrate, in reality, rhetorical efforts aimed at external audiences can and will stray from and fall short of ideals. We contend that detailed, realistic considerations of ideals and the potentials of a rhetorical perspective, such as those that are offered in these essays, will keep all of us moving in the right direction - one that brings everyone closer to helping achieve organizational rhetoric that betters society.

\section{Declaration of Conflicting Interests}

The authors declared no potential conflicts of interest with respect to the research, authorship, and/or publication of this article.

\section{Funding}

The authors received no financial support for the research, authorship, and/or publication of this article.

\section{References}

Bitzer. L. (1968). The rhetorical situation. Philosophy and Rhetoric, 1(1) 1-14.

Boyd, J., \& Waymer, D. (2011). Organizational Rhetoric: A Subject of Interest(s). Management Communication Quarterly, 25, 474-493. 
Burke, K. (1969). A rhetoric of motives. Berkeley: University of California Press.

Cloud, D. (1994). The materiality of discourse as oxymoron. Western Journal of Communication, 58, 141-163.

Deetz, S. (1992). Democracy in an age of corporate colonization: Developments in communication and the politics of everyday life. Albany, NY: SUNY.

Deetz, S. (2008). Engagement as co-generative theorizing. Journal of Applied Communication Research, 36, 289-297.

Feldner, S. L., \& Meisenbach, R. J. (2007). Saving Disney: Finding a voice for (counter) publics through the Internet. In S. C. Duhé (Ed.), New media and public relations (pp. 189-201). New York, NY: Peter Lang.

Hoffman, M. F., \& Ford, D. J. (2010). Organizational rhetoric: Situations and strategies. Thousand Oaks, CA: SAGE.

Kent, M. L., \& Taylor, M. (2002). Toward a dialogic theory of public relations. Public Relations Review, 28(1), 21-37.

Putnam, L. L., \& Fairhurst, G. T. (2001). Discourse analysis in organizations: Issues and concerns. In F. M. Jablin \& L. L. Putnam (Eds.), The new handbook of organizational communication: Advances in theory, research, and methods (pp. 78-136). Thousand Oaks, CA: SAGE.

Taylor, M. (2011). Building Social Capital Through Rhetoric and Public Relations. Management Communication Quarterly, 25, 436-454.

Weick, K. E. (1993). The collapse of sensemaking in organizations: The Mann Gulch disaster. Administrative Science Quarterly, 38, 628-652.

Weick, K. E. (1995). Sensemaking in organizations. Thousand Oaks, CA: SAGE.

\section{Bios}

Rebecca J. Meisenbach (PhD, Purdue University, 2004) is an assistant professor in the Department of Communication at the University of Missouri. Her research addresses issues of identity and ethics in relation to nonprofit and gendered organizing.

Sarah Bonewits Feldner (PhD, Purdue University, 2002) is an assistant professor in communication studies at Marquette University. Her research focuses on the interrelationships between organizational practices, societal discourses, and identity construction. 